\title{
Ceramics Sugar Jars Pieces from Aveiro Production
}

\author{
S. Moutinho ${ }^{1(\bowtie)}$, C. Costa $^{1,2}$, Â. Cerqueira $^{2}$, C. Sequeira ${ }^{2}$,

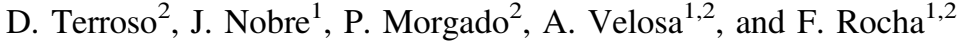 \\ ${ }^{1}$ RISCO, Civil Engineering Department, University of Aveiro, \\ 3810-193 Aveiro, Portugal \\ sara.moutinho@ua.pt \\ ${ }^{2}$ GeoBioTec, Geosciences Department, University of Aveiro, \\ 3810-193 Aveiro, Portugal
}

\begin{abstract}
Ceramics sugar jars pieces are, from morphological point of view, conical containers of fired clay with a hole in the vertex, which were used to sugar cane pulp maturation into sugar cake. These ceramic materials were produced in Aveiro given the existence of local raw material. Also, this occurrence of geological deposits exploited for red clays allowed the local development of strong pottery production center, transforming the city of Aveiro into one of the major Portuguese cultural heritage sites very rich in traditional ceramic tiles (azulejos) and other ceramic products. After local manufacture, the ceramic sugar jars pieces were exported as sugar production devices for Madeira island, Cape Verde archipelago and later, for Brazil. Also, these materials were found in buildings construction. So, this work focuses on the characterization of ceramic sugar jars produced in Aveiro and its construction use comparing with properties of other ceramics, justifying their preference for export to several countries of the world.
\end{abstract}

Keywords: Ceramic products $\cdot$ Sugar jars pieces $\cdot$ Properties ·

Construction elements

\section{Introduction}

The use of ceramic sugar jars pieces in ancient masonry walls in the Aveiro district reflects the use of these materials in construction beyond the production and transportation of sugar (Nobre 2017). Ceramic sugar jars materials were produced in Aveiro given the existence of raw material in abundance and of very good quality. In the fiftieth century the production center of Barreiro (close to Lisbon) would have ceased production and until the independence of Brazil, in the early nineteenth century, Aveiro would have been the only producer of these ceramic materials in Portugal (Morgado 2014). This production will have provided intense trade with the major sugar producing centers. Due to the local absence of natural stone for construction, the rejected/surplus ceramics were used as building material on the walls. Recently, following old house demolitions in the city of Aveiro, whole walls have been discovered with these ceramic 
materials, many of which were practically intact, which allowed the development of this comparative study.

\section{Methods and Approaches}

Mineralogical analysis was carried out by X-Ray diffraction, using a Panalytical X'Pert-Pro MPD, $\mathrm{K} \alpha \mathrm{Cu}(\lambda=1,5405 \AA)$ radiation on random-oriented powders; chemical composition was assessed by X-Ray Fluorescence using a Panalytical Axios PW4400/40 X-Ray Fluorescence spectrometer for major and trace elements and Lost on Ignition (LOI) was also determined. Compressive strength was assessed by a Shimadzu: AG-IC equipment. TGA analysis was also performed.

\section{Results and Conclusions}

The chemical and mineralogical properties of ceramics were similar, pointing to local production using only local raw materials. Quartz is present in all samples. The phyllosilicates are not present in any sample of the sugar ceramics but are present in all the remaining ceramic samples. The presence/absence of phyllosilicates is an indicator of the heating process temperature, higher on the case of the sugar ceramic jars. The compressive strength analysis of the ceramics sugar jars pieces shows higher values (mean 9.5 MPa) than other ceramics (mean 8.0 MPa).

\section{References}

Morgado P, Rocha F (2014) Produção da cerâmica do açúcar em Aveiro pode explicar origem dos Ovos moles. Univ Aveiro J

Nobre J, Faria P, Velosa AL (2017) Paredes pão-de-açúcar em edifícios de Aveiro Evolução, materiais e características. Master thesis, New University of Lisbon

Open Access This chapter is licensed under the terms of the Creative Commons Attribution 4.0 International License (http://creativecommons.org/licenses/by/4.0/), which permits use, sharing, adaptation, distribution and reproduction in any medium or format, as long as you give appropriate credit to the original author(s) and the source, provide a link to the Creative Commons license and indicate if changes were made.

The images or other third party material in this chapter are included in the chapter's Creative Commons license, unless indicated otherwise in a credit line to the material. If material is not included in the chapter's Creative Commons license and your intended use is not permitted by statutory regulation or exceeds the permitted use, you will need to obtain permission directly from the copyright holder.

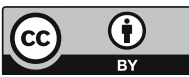

